
Maurepas Diversion Project to Gulf and Pallid Sturgeon

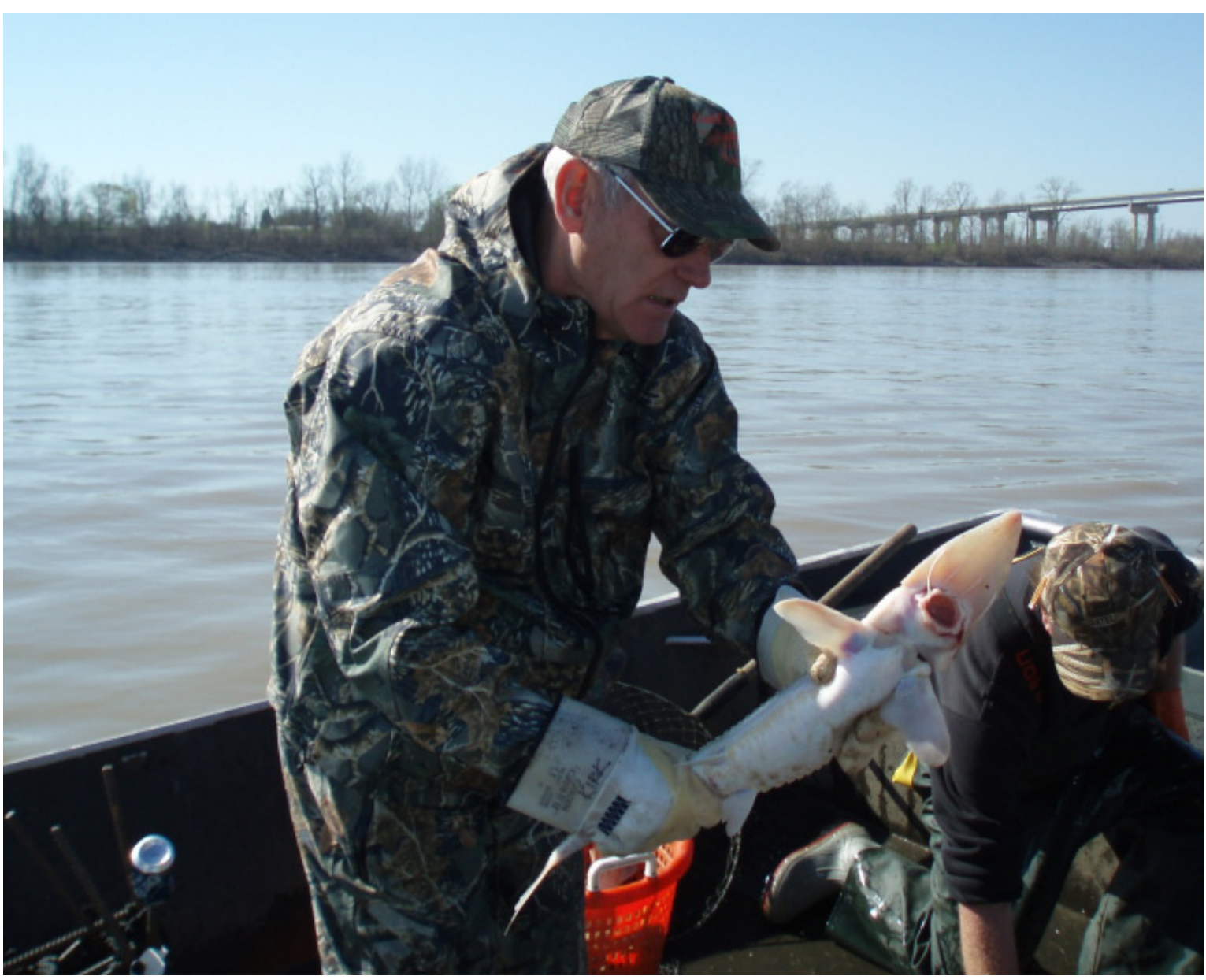




\section{Evaluation of Potential Impacts of the Lake Maurepas Diversion Project to Gulf and Pallid Sturgeon}

James P. Kirk, K. Jack Killgore, and Jan J. Hoover

Environmental Laboratory

U.S. Army Engineer Research and Development Center

3909 Halls Ferry Road

Vicksburg, MS 39180-6199

Final report

Approved for public release; distribution is unlimited.

Prepared for U.S. Environmental Protection Agency, Region 6 Dallas, TX 75202

and U.S. Army Engineer Division, Mississippi Valley Vicksburg, MS 39181-0080 


\begin{abstract}
The impacts to Gulf and pallid sturgeon from a proposed Mississippi River water diversion into the swamps bordering Lake Maurepas were evaluated. Gulf sturgeon were unlikely to be affected by the diversion due to characteristics of their life history. Adult and subadult pallid sturgeon were relatively abundant in the proposed project area and could be affected by the proposed diversion. A risk assessment was performed. Juvenile pallid sturgeon were judged to have a "low" entrainment risk due to low likelihood of their occurrence in the project area. Risk of entrainment by adults and subadults was judged "medium" due to their relatively low burst swimming speeds compared to intake velocities. Management recommendations were made to reduce or mitigate chance of their entrainment.
\end{abstract}

DISCLAIMER: The contents of this report are not to be used for advertising, publication, or promotional purposes. Citation of trade names does not constitute an official endorsement or approval of the use of such commercial products. All product names and trademarks cited are the property of their respective owners. The findings of this report are not to be construed as an official Department of the Army position unless so designated by other authorized documents. 


\section{Contents}

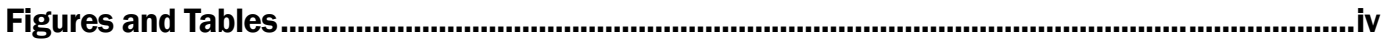

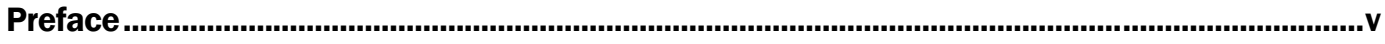

1 Introduction

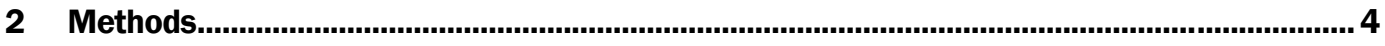

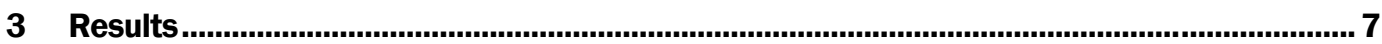

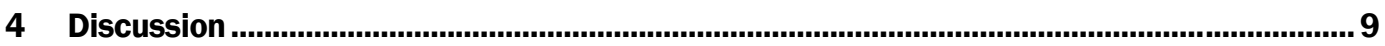

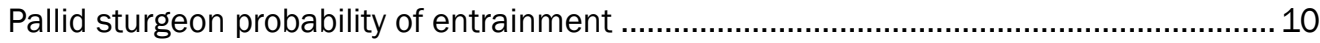

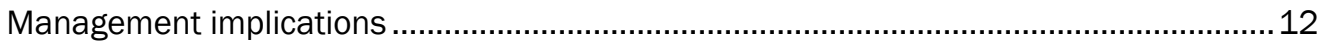

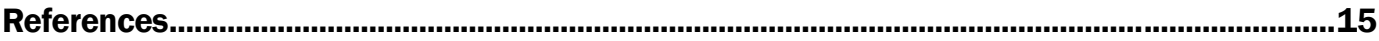

Report Documentation Page 


\section{Figures and Tables}

\section{Figures}

Figure 1. Location of the study area within the State of Louisiana .................................................... 1

Figure 2. Approximate location of the proposed diversion site and the location where

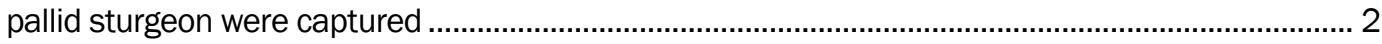

Figure 3. Elements for pallid sturgeon entrainment....................................................................... 5

\section{Tables}

Table 1. Pallid and shovelnose sturgeon captures in main channel of Mississippi River near Gramercy Bridge, LA, during 2005 and 2006.

Table 2. Risk of entrainment of pallid sturgeon by a water diversion structure at Lake Maurepas 


\section{Preface}

The work described in this report was funded by the U.S. Environmental Protection Agency (EPA) and the U.S. Army Engineer Division, Mississippi Valley.

This report was prepared by Dr. James P. Kirk, Dr. Jan J. Hoover, and Dr. K. Jack Killgore, Aquatic Ecology and Invasive Species Branch (AEISB), Ecosystem Evaluation and Engineering Division (EEED), Environmental Laboratory (EL), U.S. Army Engineer Research and Development Center (ERDC). Peer review was provided by Kenneth Teague of the EPA and David Walther of the U.S. Fish and Wildlife Service.

Bradley Lewis, Jay Collins, William Lancaster, Steven George, and Catherine Murphy of AEISB participated in field collections as did R. Timothy Ruth of the Louisiana Department of Wildlife and Fisheries (LDWF). The LDWF provided expedited permitting, telemetry-tagged Gulf sturgeon, and field sampling assistance.

ERDC supervision was provided by Dr. Timothy E. Lewis, Chief, AEISB;

Dr. David J. Tazik, Chief, EEED; and Dr. Elizabeth C. Fleming, Director, EL.

COL Richard B. Jenkins was Commander and Executive Director of ERDC. Dr. James R. Houston was Director. 


\section{Introduction}

Over the past century, flood control in the Mississippi River has reduced freshwater, nutrients, and sediment inputs that maintained swamps bordering Lake Maurepas, Louisiana. A 1,500 to 2,000 cubic feet per second (cfs) diversion from the Mississippi River is proposed to reverse habitat deterioration and improve overall water quality. The diversion from the Mississippi River would use two box culverts at a point near the Hope Canal, near River Mile (RM) 144 (see Figures 1 and 2). The major benefits of this water diversion would be:

1. Increase accretion in the swamps, thus offsetting subsidence, and ameliorate salt stress to cypress-tupelo swamps along the lake's boundaries and

2. Reverse the trend of swamp conversion to open water or marsh.

Before this project can proceed, however, evaluation must be made of its potential impacts on the endangered pallid sturgeon (Scaphirhynchus albus) and the threatened Gulf of Mexico (Gulf) sturgeon (Acipenser oxyrinchus desotoi), both of which are thought to occur in the project area.

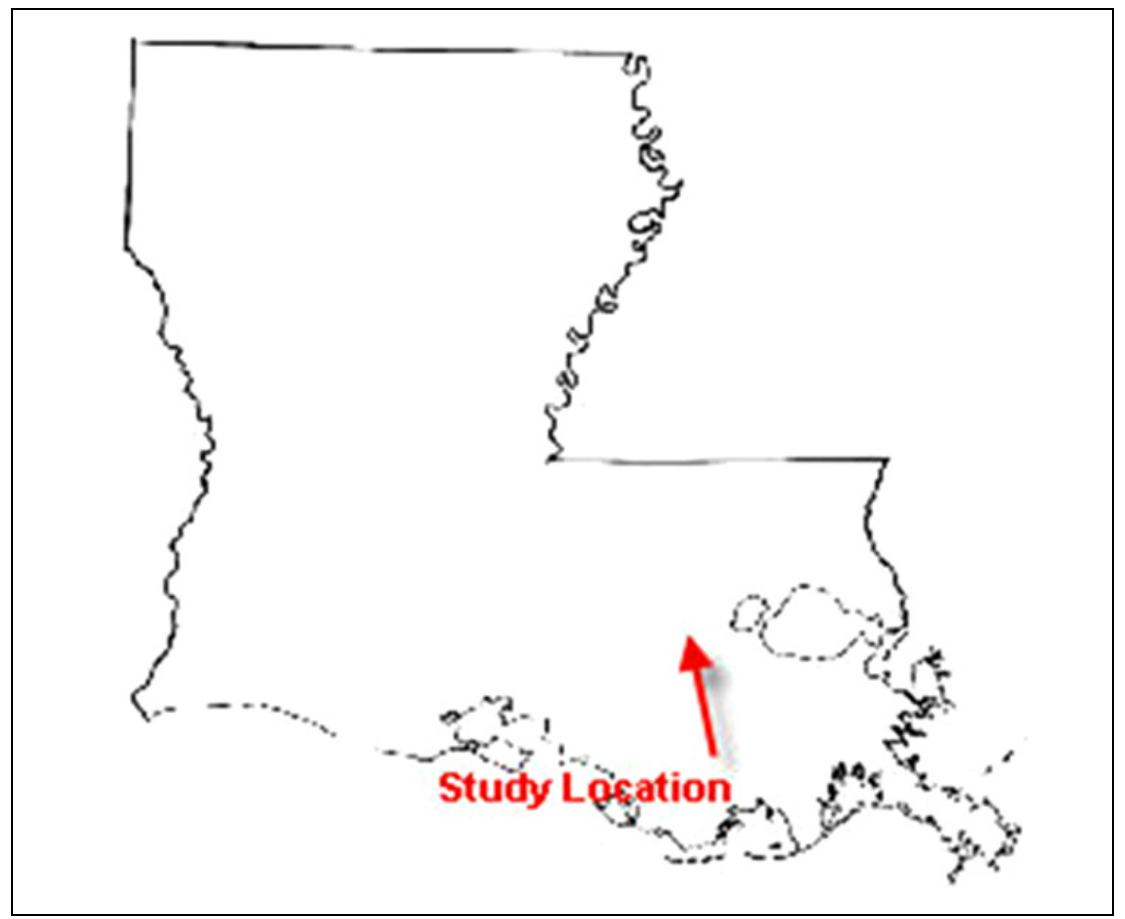

Figure 1. Location of the study area within the State of Louisiana. 


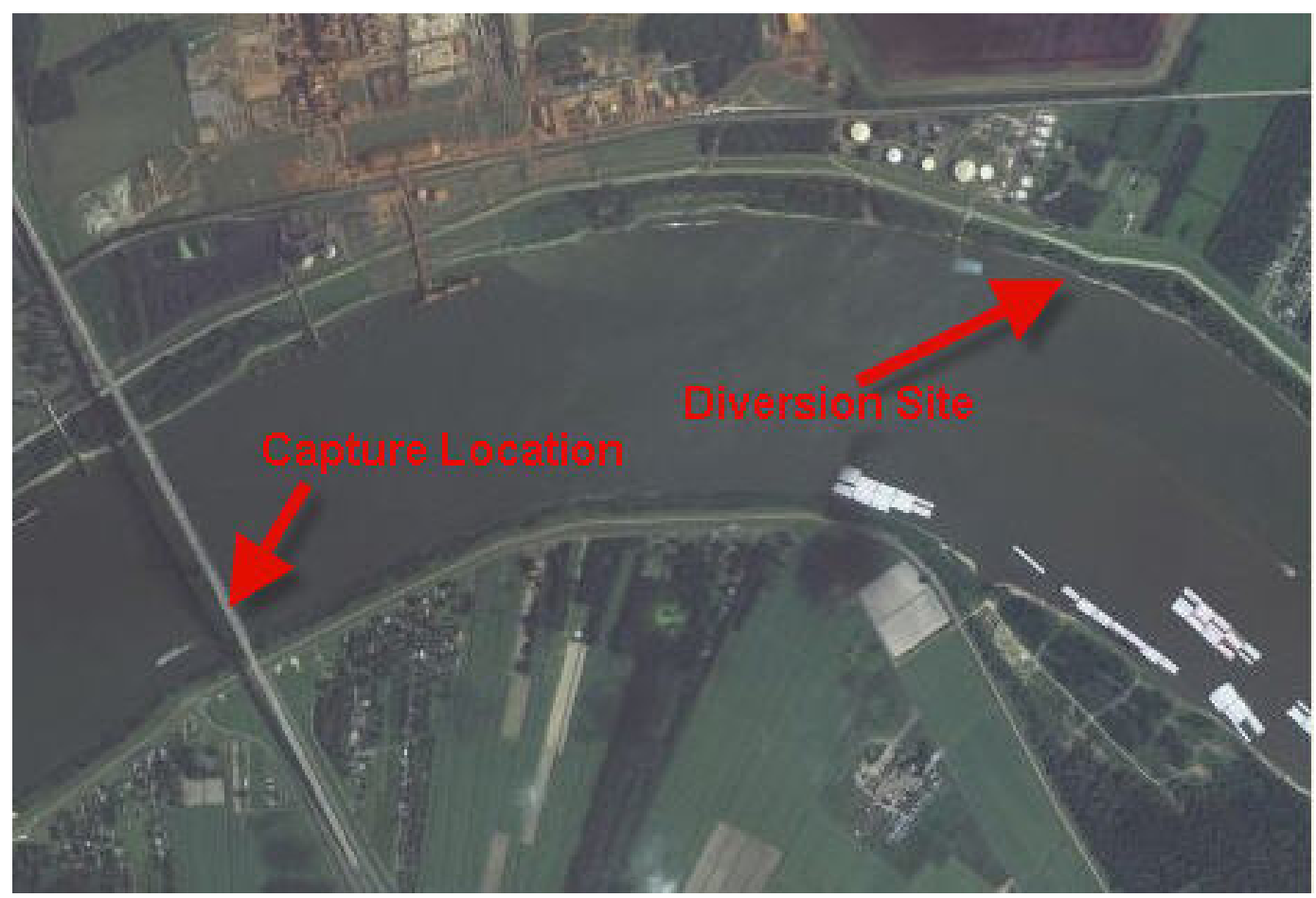

Figure 2. Approximate location of the proposed diversion site and the location where pallid sturgeon were captured.

Gulf sturgeon are diadromous (using both salt and freshwater habitats) and mature between ages 7 to 12 at a fork length (FL) of 1.2 to $1.4 \mathrm{~m}$ (Huff 1975). Ranging from Tampa Bay to the Mississippi River (Grunchy and Parker 1980), this fish was listed as threatened in 1991 (USFWS 1991). Exploitation, blockage of migration routes, and declining water quality are thought to be responsible for species decline (Wooley and Crateau 1985; Barkuloo 1988; USFWS and GSMFC 1995). Gulf sturgeon generally spend November through March in saltwater and the rest of the year in freshwater rivers (Wooley and Crateau 1985; Odenkirk 1989; Carr et al. 1996; Foster and Clugston 1997; Fox et al. 2000; Rogillio et al. 2001, 2007; Heise et al. 2004). Gulf sturgeon have been collected in tributary rivers (e.g., the Amite River) flowing into Lake Maurepas. Gulf sturgeon from the Pearl River system in Louisiana-Mississippi may also use Lake Maurepas, and this nearby system has been extensively studied (Davis et al. 1970; Rogillio 1992; Morrow et al. 1996, 1998, 1999; Rogillio et al. 2001, 2007).

The pallid sturgeon was listed as an endangered species in 1990 and occurs in the large rivers in the Mississippi River Basin (Lee et al. 1980; Killgore et al. 2007). The decline of this species is attributed to flood control and navigation projects, pollution, and overexploitation for caviar (Dryer and Sandoval 1993). Populations in the lower Mississippi River are 
probably stable, but long-term studies are required to fully evaluate population trends and habitat preferences (Killgore et al. 2007). In that regard, the U.S. Army Engineer Research and Development Center (ERDC) is conducting a multi-year study on population status and habitat requirements of pallid sturgeon in the middle and lower Mississippi River. Prior to this study, pallid sturgeon have been documented in the Mississippi River as far south as Donaldsonville, LA, but likely occur below New Orleans albeit at relatively low numbers.

In this study, researchers assessed impacts to Gulf and pallid sturgeon of diverting water from the Mississippi River into swamps around Lake Maurepas. Field studies were conducted with the following objectives:

1. Document habitat characteristics in the proposed diversion site and compare these characteristics to known pallid sturgeon habitat use patterns,

2. Determine relative abundance of both species,

3. Evaluate the impacts to Gulf sturgeon that may periodically be utilizing Lake Maurepas, and

4. Perform a risk assessment of pallid sturgeon entrainment at the proposed water diversion site. 


\section{Methods}

Gulf sturgeon in Lake Maurepas were sampled during November 2005 through June 2006 using 27.4-m experimental monofilament gill nets with stretch mesh panels varying from 102 to $229 \mathrm{~mm}$ and 3.1-m otter trawls. Concurrently, mobile sonic telemetry along a systematic grid was used to locate any of approximately 40 Gulf sturgeon telemetry-tagged in the Pearl River system by the Louisiana Department of Wildlife and Fisheries (LDWF) and the ERDC during 2001 through 2006. While sampling, habitat data were collected to describe micro- and macrohabitats. At each sampling site the following water quality parameters were measured: temperature, specific conductance, $\mathrm{pH}$, dissolved oxygen, and turbidity. Likewise, Global Positioning System (GPS) coordinates, distance to shore, depth, bottom slope, water velocities, and substrate were measured.

Pallid sturgeon in the Mississippi River near the proposed diversion site were sampled with trawls and trotlines. Age-o and juvenile pallid sturgeon were sampled during August 2005 and monthly from April through June 2006 using 3.1- and 4.9-m otter trawls. Replicate trawls approximately $0.6 \mathrm{~km}$ in length were made near the diversion site (when river currents were not too high) and at nearby sandbars because age-o and juvenile sturgeon have been captured at other sandbars in ongoing studies. Habitat data comparable to those described for Gulf sturgeon were recorded at each sampling location.

Abundance was measured in cooler months (December 2005 through April 2006) using trotlines. Once a month, eight trotlines with 60 hooks per line were fished overnight at a variety of sites near the proposed diversion site using night crawlers or crayfish for bait. Sites included: sandy bars above and below the diversion site, in the main channel at the bridge at Gramercy, LA, and near a petroleum loading dock close to the proposed diversion site (Figure 2). Because shovelnose Scaphirhynchus platorynchus were also likely to be captured, morphological and meristic data were obtained to separate pallid from shovelnose sturgeon (Murphy et al. 2007). As with trawling sites, water quality and habitat data were collected. 
A generic risk assessment for pallid sturgeon entrainment at the diversion site is presented next based on site-specific observations, construction plans, and data from previous studies. Information relevant to entrainment risk of pallid sturgeon is summarized in a format that documents the assessment process. This approach allows re-assessment of risk whenever new information is obtained (e.g., additional data on pallid sturgeon demographics, revised specifications for structure, and studies of pallid sturgeon behavior).

Protocol includes assessment of the probability of pallid sturgeon entrainment adapted from methodology used to assess probability of non-native fish establishment (Courtenay and Williams 2004; Nico et al. 2005). Elements representing a temporal sequence in the movement of the organism are identified, evaluated, and rated to determine overall risk within the pathway (ANSTF 1996). For pallid sturgeon entrainment, elements (Figure 3) are defined below.

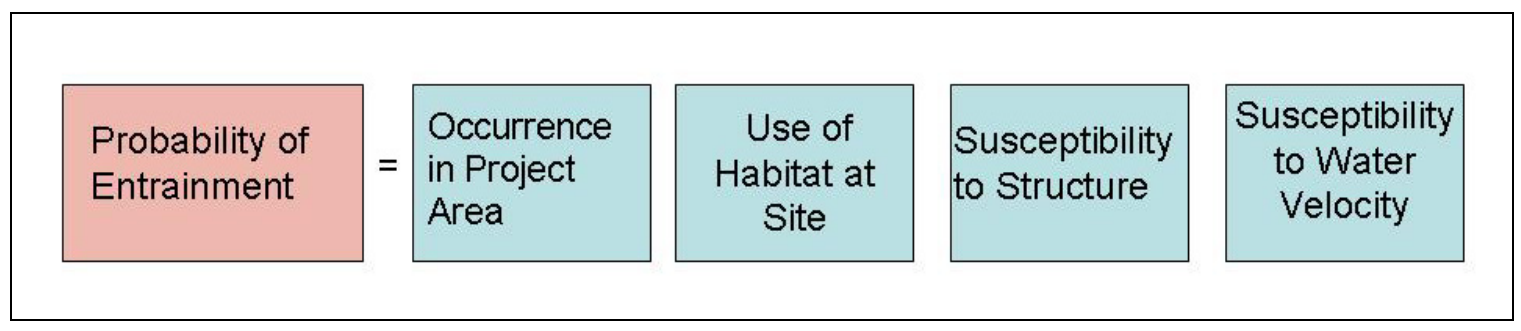

Figure 3. Elements for pallid sturgeon entrainment.

"Occurrence within the project area" is evaluated based on a single characteristic: distribution of the fish within the reach where construction and operation of the project will take place. "Use of habitat at site" is also evaluated on a single characteristic: occurrence of the fish at the location where the structure will be placed and/or in habitat similar to that in which the structure will be constructed. "Susceptibility to structure" is based on multiple characteristics of the completed structure: its suitability as a unique habitat for pallid sturgeon and the creation of flows at the same position in the water column as those occupied by the fish. "Susceptibility to water velocity" is based on swimming performance of the fish in water velocities created by diverted water considering rheotaxis (movement in response to the flow of a current), swim speeds, and stationholding behaviors. Because swimming performance of smaller sturgeon is substantially lower than that of larger sturgeon (Peake et al. 1997), juvenile fish are evaluated separately from subadult and adult fish. 
Elements are rated qualitatively on a 3-point scale for risk: low, medium, or high. Probability of entrainment is assigned the value of the element with the lowest risk rating. This estimate of risk is considered conservative since each of the elements must take place for entrainment to occur and since a combined series of probabilities results in a cumulative probability that is in reality lower than any probability of a single event (ANSTF 1996). For each element, ratings of risk were evaluated on a 5-point scale for uncertainty: very certain, reasonably certain, moderately certain, reasonably uncertain, and very uncertain. These evaluations identify elements for which more information is required for greater accuracy in risk assessment. Probability of entrainment was assigned the value with the highest degree of uncertainty as a conservative measure of confidence in the overall risk of entrainment. 


\section{Results}

No Gulf sturgeon were detected (via telemetry) nor captured using trawls or experimental gill nets in Lake Maurepas. Likewise, extensive trawling captured no age-o or juvenile pallid sturgeon at any location in the Mississippi River near the proposed water diversion site. A total of 10 pallid and 24 shovelnose sturgeon were captured using trotlines from early December of 2005 through April 2006 (see Table 1). These fish were captured at a single location: at the edge of the main channel of the Mississippi River at the Gramercy Bridge (see Figure 2). No pallid or shovelnose sturgeon were captured using similarly set trotlines near the proposed diversion site or from sand bars above and below the diversion site.

The catch per unit effort (CPUE) and pallid to shovelnose sturgeon ratio were compared with previous data for this section of the Mississippi River (Killgore et al. 2007). The established CPUE of pallid sturgeon in the Mississippi River at RM 154 to 507 was 0.31 per trotline, and the pallid to shovelnose ratio was 1:6. Based upon trotlines, the pallid sturgeon CPUE was 0.28 per trotline and not different from the value reported by Killgore et al. (2007). The ratio of pallid to shovelnose sturgeon was 1:2.4.

The habitat near the bridge was at the edge of the main channel in depths of 17.5 to $22.6 \mathrm{~m}$-current velocities ranged from 0.3 to $1.3 \mathrm{~m} / \mathrm{sec}$ and water temperatures ranged from of 8.2 to $16.6^{\circ} \mathrm{C}$. The sloping bottom was predominately sand with some gravel. The habitat near the proposed diversion site was deep (approximately 10 to $25 \mathrm{~m}$ ), not in the main channel, and had a bottom comprised of sand and mud. 
Table 1. Pallid and shovelnose sturgeon captures in main channel of Mississippi River near Gramercy Bridge, LA, during 2005 and 2006.

\begin{tabular}{|c|c|c|c|c|}
\hline Date & Species & Total length, mm & Depth, $m$ & Water Temperature, ${ }^{\circ} \mathrm{C}$ \\
\hline \multirow[t]{3}{*}{$1 \mathrm{Dec} 05$} & \multirow[t]{2}{*}{ shovelnose } & 600 & 17.5 & 13.6 \\
\hline & & 621 & & \\
\hline & pallid & 788 & & \\
\hline \multirow[t]{9}{*}{25 Jan 06} & \multirow[t]{5}{*}{ shovelnose } & 535 & 22.7 & 8.4 \\
\hline & & 514 & & \\
\hline & & 479 & & \\
\hline & & 543 & & \\
\hline & & 563 & & \\
\hline & \multirow[t]{4}{*}{ pallid } & 831 & & \\
\hline & & 823 & & \\
\hline & & 860 & & \\
\hline & & 735 & & \\
\hline \multirow[t]{19}{*}{2 Mar 06} & \multirow[t]{16}{*}{ shovelnose } & 623 & 20.6 & 8.2 \\
\hline & & 600 & & \\
\hline & & 700 & & \\
\hline & & 523 & & \\
\hline & & 547 & & \\
\hline & & 589 & & \\
\hline & & 450 & & \\
\hline & & 430 & & \\
\hline & & 552 & & \\
\hline & & 683 & & \\
\hline & & 593 & & \\
\hline & & 565 & & \\
\hline & & 597 & & \\
\hline & & 561 & & \\
\hline & & 542 & & \\
\hline & & 470 & & \\
\hline & \multirow[t]{3}{*}{ pallid } & 773 & & \\
\hline & & 623 & & \\
\hline & & 709 & & \\
\hline \multirow[t]{3}{*}{13 April 06} & shovelnose & 545 & 15.3 & 16.6 \\
\hline & \multirow[t]{2}{*}{ pallid } & 762 & & \\
\hline & & 713 & & \\
\hline
\end{tabular}




\section{Discussion}

A risk assessment for entrainment of Gulf sturgeon was not performed, since this species is unlikely to be in this reach of the Mississippi River and thus unlikely to be entrained (Douglas 1974; Ross 2001). Instead, temperature and salinity impacts caused by diverting water from the Mississippi River were evaluated for the Gulf sturgeon in and near Lake Maurepas.

No Gulf sturgeon were captured nor detected using telemetry in Lake Maurepas. However, Gulf sturgeon are likely to use or move through Lake Maurepas from tributary rivers on their annual migration to and from marine habitats (where they feed). In that regard, a review of the literature of Gulf sturgeon movements in Mississippi, Alabama, and Florida is instructive in understanding when Gulf sturgeon are likely to use Lake Maurepas and thus be influenced by project impacts (i.e., decreasing salinity and lower water temperatures).

Movements of Gulf sturgeon out of the Suwannee River in Florida were reported for October to November by Carr et al. (1996) and midSeptember through November by Foster and Clugston (1997). Movements out of the Pascagoula River system were reported to be during midOctober through late November (Heise et al. 2004).

Gulf sturgeon in the nearby Pearl River system used winter habitat in the Mississippi Sound between November and March. Starting in April, fish were located at the Rigolets Pass and mouth of the Pearl River. Movements into the Bogue Chitto and Pearl rivers began in April (Rogillio et al. 2007). In the Suwannee River, Gulf sturgeon return ranged from late February through May (Carr et al. 1996; Foster and Clugston 1997) at temperatures of approximately $22{ }^{\circ} \mathrm{C}$. Similar chronologies were found in the Apalachicola River. Wooley and Crateau (1985) found fish moved back into the river during April and May, and Odenkirk (1989) tracked return movements during March and April. Gulf sturgeon returned to the Choctawhatchee River system during March through May (Fox et al. 2000).

Thus, although some Gulf sturgeon may reside in Lake Maurepas - as they are known to do in Lake Pontchartrain - their use of the lake is likely to be 
during October or November and again during their return from marine habitats in the Mississippi Sound during February through April. Since these fish are moving into or out of saline habitats and are not feeding, changes in temperature or salinity caused by the diversion of water from the Mississippi River seem unlikely to adversely impact their populations.

A risk assessment of pallid sturgeon potentially entrained by all proposed diversion sites from the Mississippi River into the brackish waters in nearby Lake Maurepas was performed. While no direct literature on salt water tolerance of pallid sturgeon was located, it was deemed that diversion from fresh to brackish water could be lethal. Further, if the salinity levels were not lethal, the entrained pallid sturgeon would still be a loss to the Mississippi River population.

\section{Pallid sturgeon probability of entrainment}

Entrainment risk was "low" for juveniles due to low likelihood of occurrence in the project area, and "medium" for subadults and adults due to presumed lower limits on swimming capabilities of some individual fish (Table 2). Pallid sturgeon occur throughout the Mississippi River, including reaches above and below the sites of all proposed diversions (Killgore et al. 2007) and thus entrainment risks apply equally to all sites including the one near the Hope Canal. Subadult and adult pallid sturgeon are relatively abundant in the project area (see Table 1), but no small sturgeon $(<623 \mathrm{~mm}$ FL) were collected. The occurrence of subadults and adults within the project area can be accepted as "very certain," but the apparent absence of juveniles is less certain. Juvenile pallid sturgeon are rarely collected, even during spatially and temporally extensive surveys of naturally reproducing populations. Low numbers of juveniles is presumably due to specialized habitat requirements and very rapid growth of young fish. Spawning habitat of pallid sturgeon (i.e., gravel beds in swift water) was not apparent in the project area, and it is possible that juveniles do not occur in the area because spawning is taking place elsewhere. Surveys for potential spawning habitat and additional sampling using gear with higher selectivity for juvenile sturgeon (e.g., trawling, small mesh gillnets) during periods of likely occurrence (e.g., late spring, early summer) could confirm or refute their presence in the project area. 
Table 2. Risk of entrainment of pallid sturgeon by a water diversion structure at Lake Maurepas.

\begin{tabular}{|l|l|l|l|l|l|}
\hline \multirow{2}{*}{ Element } & \multirow{2}{*}{ Characteristics } & \multicolumn{2}{|c|}{ Juveniles } & \multicolumn{2}{c|}{ Subadults \& Adults } \\
\cline { 3 - 6 } & Rating & Uncertainty & Rating & Uncertainty \\
\hline $\begin{array}{l}\text { Occurrence in } \\
\text { Project Area }\end{array}$ & $\begin{array}{l}\text { Distribution of } \\
\text { sturgeon }\end{array}$ & Low & $\begin{array}{l}\text { Reasonably } \\
\text { uncertain }\end{array}$ & High & Very certain \\
\hline $\begin{array}{l}\text { Use of Habitat } \\
\text { at Site }\end{array}$ & $\begin{array}{l}\text { Abundance of } \\
\text { sturgeon }\end{array}$ & Low & $\begin{array}{l}\text { Reasonably } \\
\text { uncertain }\end{array}$ & High & Very certain \\
\hline $\begin{array}{l}\text { Susceptibility to } \\
\text { Structure }\end{array}$ & $\begin{array}{l}\text { Suitability of habitat } \\
\text { for sturgeon } \\
\text { Vertical position of } \\
\text { withdrawal }\end{array}$ & High & $\begin{array}{l}\text { Moderately } \\
\text { certain }\end{array}$ & High & $\begin{array}{l}\text { Reasonably } \\
\text { certain }\end{array}$ \\
\hline $\begin{array}{l}\text { Susceptibility to } \\
\text { Velocity }\end{array}$ & $\begin{array}{l}\text { Swimming } \\
\text { performance of } \\
\text { sturgeon }\end{array}$ & High & Very certain & Medium & $\begin{array}{l}\text { Reasonably } \\
\text { certain }\end{array}$ \\
\hline Risk & All of the above & Low & $\begin{array}{l}\text { Moderately } \\
\text { certain }\end{array}$ & Medium & $\begin{array}{l}\text { Reasonably } \\
\text { certain }\end{array}$ \\
\hline
\end{tabular}

Adult pallid sturgeon were collected at one location, the Gramercy Bridge, within 2,000 $\mathrm{m}$ of the proposed diversion structure (Figure 2). Also, it is not uncommon to collect adult pallid sturgeon near steep, vertical banks (sandbar "reefs") similar to the littoral habitat of the proposed site. Consequently, the probability of use of the site where the structure will be constructed is "high" and "very certain" for subadult and adult fish. Juvenile fish are not documented from the area so use of habitat is presumed "low." Pending targeted sampling for small fish, this rating is "reasonably uncertain."

Susceptibility of fish to the proposed culvert is "high" for juveniles and for subadults and adults. Pallid sturgeon in the Mississippi River are frequently found in the vicinity of man-made structures (e.g., dikes). Such structures provide attractive areas of shelter from main channel water velocities. They also provide hard, permanent substrates for benthic invertebrates (e.g., common net spinning caddisflies, Hydropsychidae) and fishes (e.g., chubs, Macrhybopsis spp.) eaten by pallid sturgeon (Hoover et al. 2007). The likelihood that pallid sturgeon of any size would exploit a culvert (and any associated embayment) as a refugium and/or feeding ground is "high." Flows in the culvert will be controlled by vertical lift gates and water diverted through the bottom of the structure (Dr. Patricia Taylor, U.S. Environmental Protection Agency [EPA], 
personal communication). Consequently, sturgeon attracted to the culvert seeking shelter or food will be placed in direct proximity to potentially entraining flows diverted through the structure. This rating is only "moderately certain" because it is largely conjectural for juveniles (due to limited empirical data). It is "reasonably certain" for subadults and adults since these fish have been frequently confirmed near similar structures.

Susceptibility to water velocities in the culvert is "high" for juveniles, but only "medium" for subadults and adults due to greater swimming capabilities of larger fish. Pallid sturgeon of all sizes are conspicuously rheotactic and exhibit complex station-holding behaviors. Swimming speeds, based on endurance, however, are highly variable among (and within) age classes. Escape speeds (i.e., swimming speeds that can be maintained for up to $1 \mathrm{~min}$ ) have been measured for juvenile pallid sturgeon 74-205 mm FL and range from 35-75 cm/s (Adams et al. 1999; Hoover et al. 2005). Escape speeds for subadult and adult pallid sturgeon have not been measured but are probably in excess of $120 \mathrm{~cm} / \mathrm{s}$ (pallid sturgeon were captured in this study in currents as fast as $130 \mathrm{~cm} / \mathrm{s})$. This estimate is based on data for shovelnose sturgeon, which have nearly identical swimming endurance to pallid sturgeon (Adams et al. 1997). Shovelnose sturgeon $>530 \mathrm{~mm}$ SL are capable of swimming at $49-71 \mathrm{~cm} / \mathrm{s}$ for $60 \mathrm{~min}$ (Parsons et al. 2003) and 65-116 cm/s for $15 \mathrm{~min}$ (Adams et al. 2003). An extrapolated swim speed of $120-150 \mathrm{~cm} / \mathrm{s}$ for $1 \mathrm{~min}$ would be conservative. Projected flows through the culvert could be $100-150 \mathrm{~cm} / \mathrm{s}$ (EPA, preliminary communication). If flows approach this range however, entrainment of most juveniles and some of the slower-swimming larger fish would be likely. Rating is "very certain" for juveniles because of data from multiple laboratory studies. Rating is "reasonably certain" for subadults and adults since shovelnose sturgeon data served as surrogates for pallid sturgeon and since trends in swimming performance were extrapolated from observed values of endurance.

\section{Management implications}

Risk assessment indicates several critical information needs and possible mitigation actions. Uncertainty in risk ratings for several elements could be reduced with data on pallid sturgeon demographics (i.e., occurrence of juveniles in project area), flow fields around the culvert (i.e., water velocities at varying distances and depths from gate), and frequency of entrainment of riverine species by diversion structures (i.e., sturgeons and suckers that have passed through large culverts). Additional field studies 
at the site for the planned Lake Maurepas structure and the existing Caernarvon and Davis Pond structures are warranted.

Risk of pallid sturgeon entrainment could be reduced in several ways. Withdrawal of water from near the surface of the river (based upon river stage and season) would make entrainment less likely since pallid sturgeon swim close to the river bottom and rarely approach the water's surface. Also, larger or a greater number of gates to distribute flow (and reduce velocity of exiting water through any single gate) would make it possible for sturgeon to resist flow by creating water velocities lower than escape speeds of most fish. Rough or complex substrates (e.g., scarified concrete, rip rap, etc.) directly in front of the gates (as currently envisioned by the designers) would also enable pallid sturgeon to resist entraining flows by providing low-velocity boundary layers and by enabling alternative low-energy station-holding behaviors such as creeping, hunkering, and tail-bracing to be used by fish (Hoover et al. 2005). Seasonal restrictions on diversion, or "windows," could minimize likelihood of entraining spawning adults (e.g., early spring) or juveniles (e.g., late spring, early summer).

Since some entrainment of pallid sturgeon is possible, mitigation strategies should at least be considered and studied. Culture and release of pallid sturgeon should be a last option for a number of reasons. Brood stock availability, genetic and behavioral considerations, as well as lack of understanding of pallid sturgeon demographics are reasons sufficient to presently recommend against this approach. Thus, mitigation resources would better be used in gaining an enhanced understanding of the pallid sturgeon demographics, swimming capabilities, and the hydraulic characteristics of the diversion structure.

The population status of pallid sturgeon in this reach should be better understood, not only for the evaluation of this project but also future lower Mississippi River water diversion projects. If the local population is robust, then some incidental entrainment losses will likely have very little impact upon the population. If the population is depressed, however, then any losses could be consequential. A local study conducted over several fall and winter periods could determine acceptable levels of entrainment using estimates of abundance, mortality, and recruitment in age-structure population models. A longer study (about 4 years and using multiple sampling gears), could be conducted within a reach perhaps 60 to $80 \mathrm{~km}$ above 
New Orleans to evaluate the impacts of existing as well as future water diversions to the local pallid sturgeon population.

With water diversion speeds potentially reaching $150 \mathrm{~cm} / \mathrm{sec}$, studies of the similar box culvert diversion structure are justified. Fine-scale studies of water velocities in the area near diversion are important because pallid sturgeon have complex swimming behaviors. A good start would be a short but intensive study at the existing Caenarvon and Davis Pond structures to determine fine-scale variation in water velocities in a box culvert as well as velocities in the outlet channel. The results could be paired with laboratory swimming studies of adult pallid and/or shovelnose sturgeons. Taken together, these studies could be used to provide input into biologically sound design criteria as well as to refine risk assessment. 


\section{References}

Adams, S. R., G. R. Parsons, J. J. Hoover, and K. J. Killgore. 1997. Observations of swimming ability in shovelnose sturgeon (Scaphirhynchus platorynchus). Journal of Freshwater Ecology 12:631-633.

Adams, S. R., J. J. Hoover, and K. J. Killgore. 1999. Swimming endurance of juvenile pallid sturgeon, Scaphirhynchus albus. Copeia (3):802-807.

Adams, S. R., G. L. Adams, and G. R. Parsons. 2003. Critical swimming speed and behavior of juvenile shovelnose sturgeon and pallid sturgeon. Transactions of the American Fisheries Society 132:392-397.

ANSTF (Aquatic Nuisance Species Task Force) 1996. Generic nonindigenous aquatic organisms risk analysis review process. Risk Assessment and Management Committee 1998-693-132. Washington, DC: U.S. Government Printing Office.

Barkuloo, J. M. 1988. Report on the conservation status of the Gulf of Mexico sturgeon, Acipenser oxyrhynchus desotoi. Panama City, FL: U.S. Fish and Wildlife Service.

Carr, S. H., F. Tatman, and F. A. Chapman. 1996. Observations on the natural history of the Gulf of Mexico sturgeon (Acipenser oxyrinchus desotoi, Vladykov, 1955) in the Suwannee River, southeastern United States. Ecology of Freshwater Fish $5: 169-174$.

Courtenay, W. R., and J. D. Williams. 2004. Snakehead (Pisces, Channidae): A biological synopsis and risk assessment. U.S Geological Society Circular 1251.

Davis, J. T., B. J. Fontenot, C. E. Hoenke, A. M. Williams, and J. S. Hughes. 1970. Ecological factors affecting anadromous fishes of Lake Pontchartrain and its tributaries. Fisheries Bulletin Number 9. Baton Rouge: Louisiana Wildlife and Fisheries Commission.

Douglas, N. H. 1974. Freshwater fishes of Louisiana. Baton Rogue, LA: Claitor's Publishing Division.

Dryer, M. P., and A. J. Sandoval. 1993. Recovery plan for the pallid sturgeon (Scaphirhynchus albus). Region 6 report. Denver, CO: U.S. Fish and Wildlife Service.

Foster, A. M., and J. P. Clugston. 1997. Seasonal migration of Gulf sturgeon in the Suwannee River, Florida. Transactions of the American Fisheries Society 126:302-308.

Fox, D. A., J. E. Hightower, and F. M. Paruka. 2000. Gulf sturgeon spawning migration and habitat in the Choctawhatchee River system, Alabama-Florida. Transactions of the American Fisheries Society 129:811-826.

Grunchy, C. G., and B. Parker. 1980. Acipenser oxyrhynchus (Mitchill), Atlantic sturgeon. In Atlas of North American freshwater fishes, ed. D. S. Lee et al., 41. Raleigh: North Carolina Museum of Natural History. 
Heise, R. J., W. T. Slack, S. T. Ross, and M. A. Dugo. 2004. Spawning and associated movement patterns of Gulf sturgeon in the Pascagoula River drainage, Mississippi. Transactions of the American Fisheries Society 133:221-230.

Hoover, J. J., S. G. George, and K. J. Killgore. 2007. Diet of shovelnose sturgeon and pallid sturgeon in the free-flowing Mississippi River. Journal of Applied Ichthyology (in press).

Hoover, J. J., K. J. Killgore, D. G. Clarke, H. Smith, A. Turnage, and J. Beard. 2005. Paddlefish and sturgeon entrainment by dredges: Swimming performance as an indicator of risk. DOER Technical Notes Collection (ERDC TN-DOER-E22). Vicksburg, MS: U.S. Army Engineer Research and Development Center. http://el.erdc.usace.army.mil/elpubs/pdf/doere22.pdf.

Huff, J. A. 1975. Life history of the Gulf of Mexico Sturgeon, Acipenser oxyrhyncus desotoi, in the Suwannee River, Florida. Marine Resource Publication 16. St. Petersburg: Florida Department of Natural Resources.

Killgore, K. J., J. J. Hoover, S. G. George, B. R. Lewis, C. E. Murphy, and W. E. Lancaster. 2007. Distribution and abundance of pallid sturgeon and shovelnose sturgeon in the free-flowing Mississippi River. Journal of Applied Ichthyology (in press).

Lee, D. S., C. R. Gilbert, C. H. Hocutt, R. E. Jenkins, D. E. McAllister, and J. R. Stauffer, Jr., ed. 1980. Atlas of North American freshwater fishes. Raleigh: North Carolina State Museum of Natural History.

Morrow, J. V., Jr., J. P. Kirk, K. J. Killgore, and H. E. Rogillio. 1996. Distribution and population attributes of Gulf sturgeon in the lower Pearl River system, Louisiana. Proceedings Annual Conference of the Southeastern Association of Fish and Wildlife Agencies 50:79-90.

Morrow, J. V., Jr., J. P. Kirk, K. J. Killgore, H. E. Rogillio, and C. Knight. 1998. Status and recovery potential of Gulf of Mexico sturgeon in the Pearl River system, Louisiana-Mississippi. North American Journal of Fisheries Management 18:798-808.

Morrow, J. V., Jr., J. P. Kirk, K. J. Killgore, and H. E. Rogillio. 1999. Recommended enhancements to the Gulf sturgeon recovery and management plan based upon Pearl River studies. North American Journal of Fisheries Management 19:11171121.

Murphy, C. E., J. J. Hoover, S. G. George, and K. J. Killgore. 2007. Morphometric variation among river sturgeons (Scaphirhynchus spp.) in the middle and lower Mississippi River. Journal of Applied Ichthyology (in press).

Nico, L. G., J. D. Williams, and H. L. Jelks. 2005. Black carp: biological synopsis and risk assessment of an introduced fish. Bethesda, MD: American Fisheries Society.

Odenkirk, J. S. 1989. Movements of the Gulf of Mexico sturgeon in the Apalachicola River, Florida. Proceedings, Annual Conference of the Southeastern Association of Fish and Wildlife Agencies 43:230-238. 
Parsons, G. R., J. J. Hoover, and K. J. Killgore. 2003. Effect of pectoral fin ray removal on station-holding ability of shovelnose sturgeon. North American Journal of Fisheries Management 23:742-747.

Peake, S., F. W. H. Beamish, R. S. McKinley, and C. Katapodis. 1997. Relating swimming performance of lake sturgeon, Acipenser fulvescens, to fishway design. Canadian Journal of Fisheries and Aquatic Science 54:1361-1366.

Rogillio, H. E. 1992. Status survey of Gulf sturgeon in Louisiana. Project E1-1 report. Baton Rouge: Louisiana Department of Wildlife and Fisheries.

Rogillio, H. E., E. A. Rabalais, J. S. Forester, C. N. Doolittle, W. J. Granger, and J. P. Kirk. 2001. Status, movement and habitat use of Gulf sturgeon in the Lake Pontchartrain basin, Louisiana. Final Report, Louisiana Department of Wildlife and Fisheries and National Fish and Wildlife Foundation. Washington, DC: Shell Marine Habitat Program.

Rogillio, H. E., R. T. Ruth, E. H. Behrens, C. N. Doolittle, W. J. Granger, and J. P. Kirk. 2007. Gulf sturgeon movements in the Pearl River drainage and the Mississippi Sound. North American Journal of Fisheries Management 27:89-95.

Ross, S. T. 2001. The inland fishes of Mississippi. Jackson, MS: University Press of Mississippi.

U.S. Fish and Wildlife Service (USFWS). 1991. Endangered and threatened wildlife and plants; threatened status for Gulf sturgeon. Federal Register 56 (30 Sep 1991):49653-49658.

USFWS and Gulf States Marine Fisheries Commission (GSMFC). 1995. Gulf sturgeon (Acipenser oxyrinchus desotoi) recovery/management plan. Atlanta, GA: USFWS Southeast Region.

Wooley, C. M., and E. J. Crateau. 1985. Movement, microhabitat, exploitation, and management of Gulf of Mexico sturgeon, Apalachicola River, Florida. North American Journal of Fisheries Management 5:590-605. 


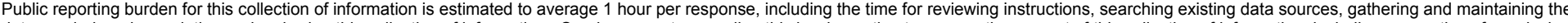

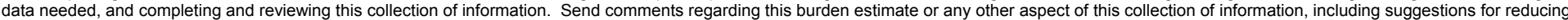

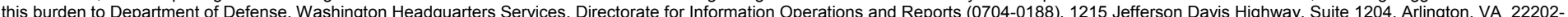

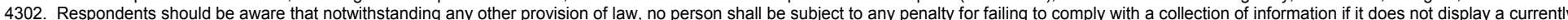
valid OMB control number. PLEASE DO NOT RETURN YOUR FORM TO THE ABOVE ADDRESS.

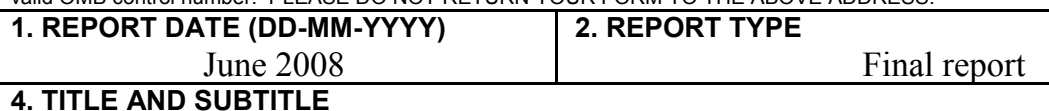

4. TITLE AND SUBTITLE

Evaluation of Potential Impacts of the Lake Maurepas Diversion Project to Gulf and Pallid Sturgeon

3. DATES COVERED (From - To)

5a. CONTRACT NUMBER

5b. GRANT NUMBER

5c. PROGRAM ELEMENT NUMBER

\section{AUTHOR(S)}

James P. Kirk, K. Jack Killgore, and Jan J. Hoover

\section{5d. PROJECT NUMBER}

5e. TASK NUMBER

5f. WORK UNIT NUMBER

\section{PERFORMING ORGANIZATION NAME(S) AND ADDRESS(ES)}

U.S. Army Engineer Research and Development Center

Environmental Laboratory

8. PERFORMING ORGANIZATION REPORT NUMBER

3909 Halls Ferry Road

ERDC/EL TR-08-19

Vicksburg, MS 39180-6199

\section{SPONSORING / MONITORING AGENCY NAME(S) AND ADDRESS(ES)}

U.S. Environmental Protection Agency, Region 6

1445 Ross Avenue, Suite 1200

Dallas, TX 75202;

U.S. Army Engineer Division, Mississippi Valley

PO Box 80

Vicksburg, MS 39181-0080

\section{DISTRIBUTION / AVAILABILITY STATEMENT}

Approved for public release; distribution is unlimited.

\section{SUPPLEMENTARY NOTES}

\section{ABSTRACT}

The impacts to Gulf and pallid sturgeon from a proposed Mississippi River water diversion into the swamps bordering Lake Maurepas were evaluated. Gulf sturgeon were unlikely to be affected by the diversion due to characteristics of their life history. Adult and subadult pallid sturgeon were relatively abundant in the proposed project area and could be affected by the proposed diversion. A risk assessment was performed. Juvenile pallid sturgeon were judged to have a "low" entrainment risk due to low likelihood of their occurrence in the project area. Risk of entrainment by adults and subadults was judged "medium" due to their relatively low burst swimming speeds compared to intake velocities. Management recommendations were made to reduce or mitigate chance of their entrainment.

\section{SUBJECT TERMS}

$\begin{array}{ll}\text { Pallid sturgeon } & \text { Risk analysis }\end{array}$

Restoration Water diversion

\begin{tabular}{|c|c|c|c|c|c|}
\hline \multicolumn{3}{|c|}{ 16. SECURITY CLASSIFICATION OF: } & \multirow{2}{*}{$\begin{array}{l}\text { 17. LIMITATION } \\
\text { OF ABSTRACT }\end{array}$} & \multirow{2}{*}{$\begin{array}{l}\text { 18. NUMBER } \\
\text { OF PAGES } \\
23\end{array}$} & \multirow{2}{*}{$\begin{array}{l}\text { 19a. NAME OF RESPONSIBLE PERSON } \\
\begin{array}{l}\text { 19b. TELEPHONE NUMBER } \\
\text { (include area code) }\end{array}\end{array}$} \\
\hline $\begin{array}{l}\text { a. REPORT } \\
\text { UNCLASSIFIED }\end{array}$ & $\begin{array}{l}\text { b. ABSTRACT } \\
\text { UNCLASSIFIED }\end{array}$ & $\begin{array}{l}\text { c. THIS PAGE } \\
\text { UNCLASSIFIED }\end{array}$ & & & \\
\hline
\end{tabular}

